\title{
Measuring the Dynamic Characteristics of Electric Motors
}

\author{
G. Á. SZIKI ${ }^{1}$, A. SZÁNTó ${ }^{2}$, K. SARVAJCZ ${ }^{3}$
}

1University of Debrecen, Faculty of Engineering, Department of Basic Technical Studies, szikig@eng.unideb.hu 2University of Debrecen, Faculty of Engineering, Department of Basic Technical Studies, szanto.attila93@gmail.com

${ }^{3}$ University of Debrecen, Faculty of Engineering, Mechatronics Department, sarvajcz@eng.unideb.hu

Abstract. In our previous publications [1, 2], we described our vehicle dynamics simulation program which was developed in MATLAB environment. We also discussed its use for optimizing the technical parameters of electric driven vehicles. We detailed the model and simulation of the series wound DC motor which is part of the program. Besides, we described the experimental procedure by which we can determine the electromagnetic characteristics of the motor from the input parameters of the simulation program. In the present publication we deal with the determination of the dynamic characteristics of the motor (the moment of inertia of the rotor, bearing and brush resistance torques) experimentally. Knowing the above mentioned electromagnetic and dynamic characteristics, we can carry out the simulation of the motor and the results of the simulation can be compared to the results of the test measurements.

\section{Introduction}

Over the past decade, we have made considerable efforts in the field of talent care $[3,4,5,6]$ at the Faculty of Engineering of the University of Debrecen. In the framework of this, several student teams were involved in different kinds of activities at our Faculty, with the guidance of our university teachers. They had remarkable achievements at competitions that were organized for alternative driven vehicles (Shell Eco-Marathon, Pneumobile Competition, MVM Energy Race).

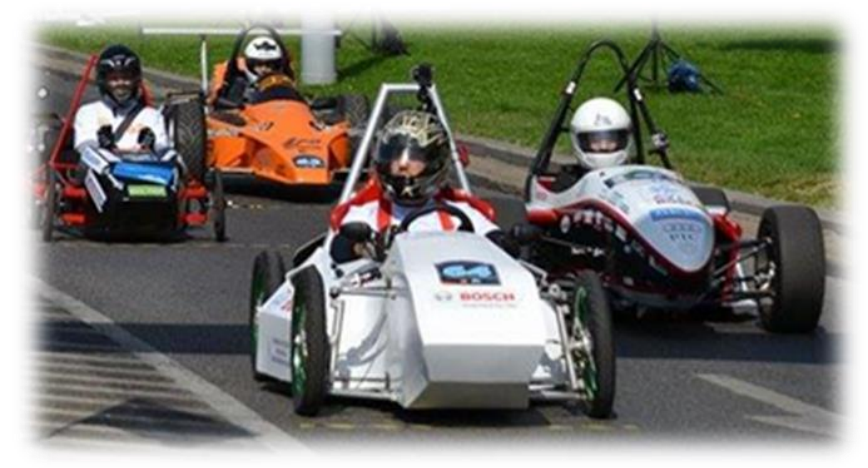

Figure 1. On the MVM Energy Race.

To achieve good results in competitions in the long term, it is important to develop the vehicles continuously, using up-to-date mathematical and IT tools of dynamic modelling and simulation - just 
like in other engineering and scientific areas $[7,8,9,10,15,16,17,18]$. In the course of this, we developed a vehicle dynamics simulation program in MATLAB environment, which is suitable for calculating the dynamic functions (e.g. acceleration, velocity and covered distance-time functions) of a vehicle driven by a series wound DC motor from the technical data of the vehicle $[11,12,13]$. Using the above described simulation program, and with the help of an optimizing program also created in MATLAB, we can determine the optimal technical data by which we can achieve the most advantageous vehicle dynamic characteristics at different competitions.

The modelling of the series wound DC motor [1] and creating a simulation program on the basis of the model are particularly significant parts of the vehicle dynamics simulation. Using the program, and the basic electromagnetic and dynamic characteristics of the motor, we can calculate its RPM, torque and the intensity of current flowing through it as a function of time. Figure 2 shows our developed program for the simulation of a series wound DC motor.

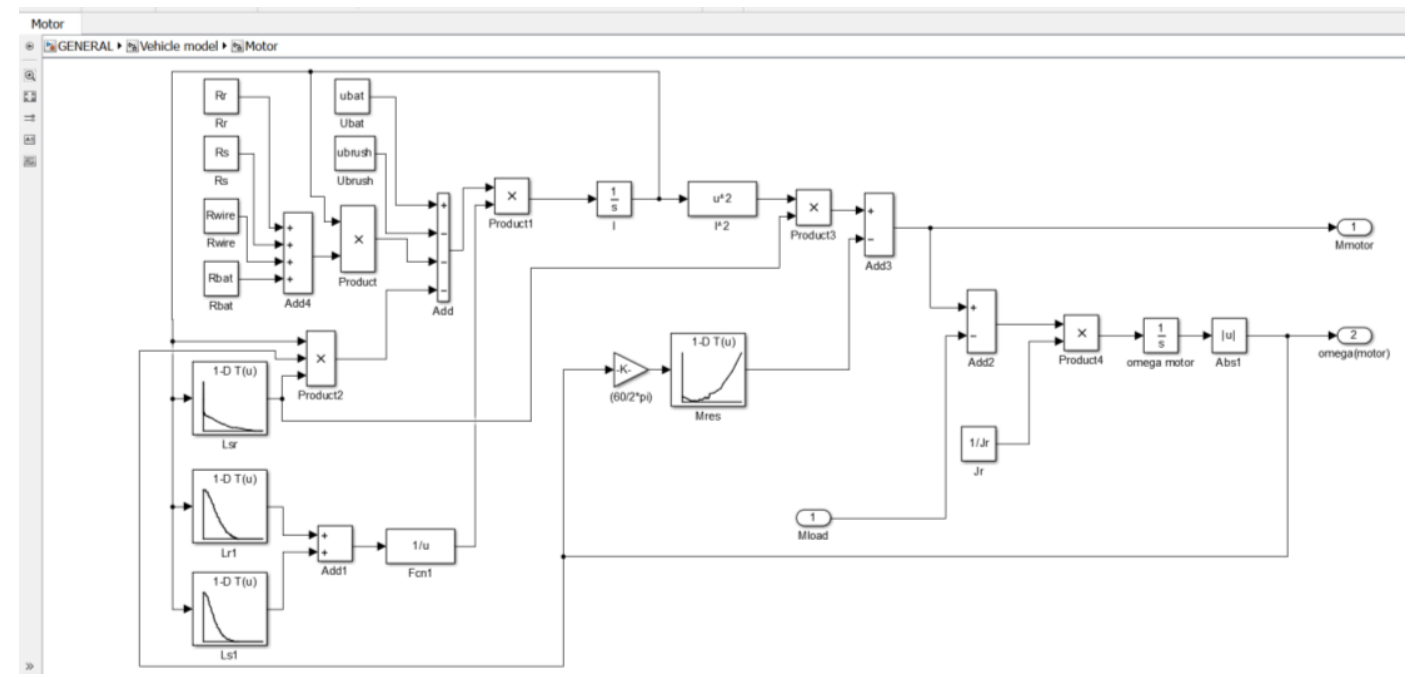

Figure 2. Program for the simulation of a series wound DC motor [1].

The determination of the electromagnetic and dynamic characteristics (electric resistance and dynamic inductance of the stator and rotor coils, the mutual inductance of the two coils, value of brush voltage, bearing and brush resistance torques, moment of inertia of the rotor) can be realised by measurements. In the present publication, we describe the experimental procedure developed for measuring the moment of inertia of the rotor and bearing and brush resistance torques.

\section{Measuring the moment of inertia of the rotor}

\section{Measuring the moment of inertia by swinging}

In literature there are several experimental methods for measuring the moment of inertia of a rotating system. There are procedures based on the principle of swinging, in which we determine the moment of inertia by measuring the period of a physical or a torsional pendulum. We can make a physical pendulum by fixing a point-like weight with a known mass to the rotor of the motor excentrically and then put the system in motion. The rotor can swing by turning over its own bearing, or, taken out of the motor, rolling on an ideal edge [14]. Applying the rolling on an ideal edge method, we can eliminate 
the disturbing effect of the bearing resistance torque, and we can gain more exact measurement results. This means that we have to take the rotor out of the motor to be able to carry out more exact measurements.

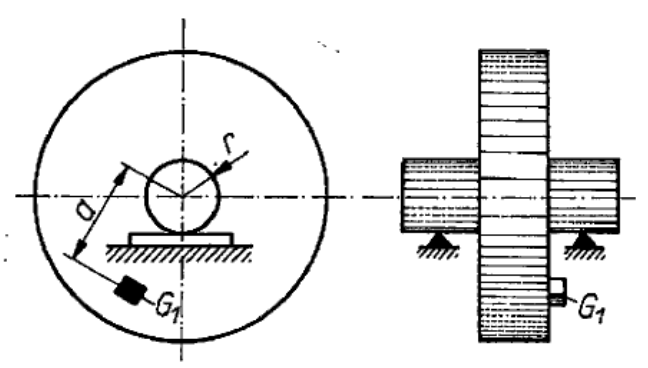

Figure 3. Determining the moment of inertia by measuring the period of a physical pendulum [14].

In case of the torsion pendulum, we hang the rotor on a torsion spring, and make the pendulum to swing. In both cases (physical and torsional pendulum), we determine the moment of inertia from the period and other data that characterise the swinging system. We must emphasise here that we have to take the rotor out of the motor in case of both of these methods to be able to carry out sufficiently precise measurements.

\section{Determining the moment of inertia by run-out measurement}

Another possibility is to perform a run-out measurement. An advantage of this method is that we do not need to take the rotor out of the motor, furthermore, the bearing and the brush resistance torques can also be measured together with the moment of inertia using the same measurement system. The disadvantage of the method is that it needs a complex measurement system.

We can carry out the measurements by applying the following measurement system:

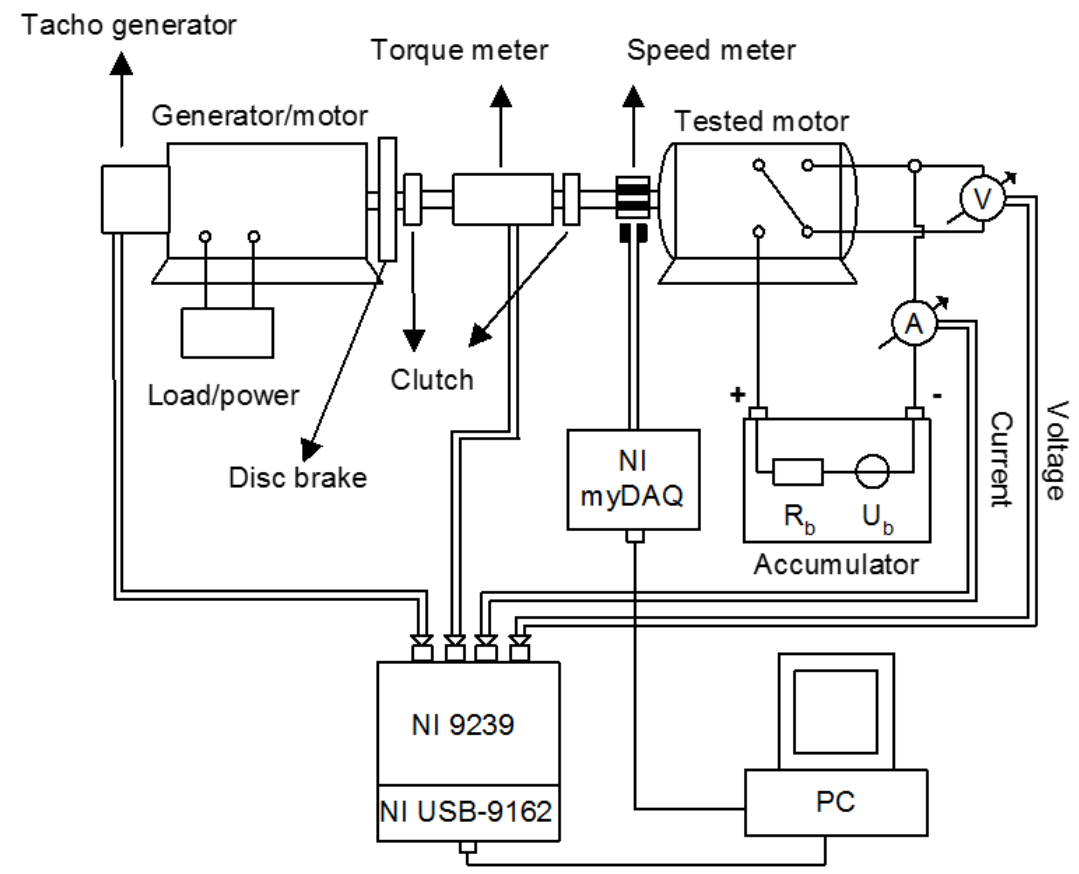

Figure 4. Measurement set-up for the run-out measurement. 
Theoretically we can apply two different methods to carry out the measurements (versions A and B).

The process of measurement (version A):

1. We speed up the analysed motor with the help of an external motor - through a torque meter and a clutch - to a given RPM (e.g. 4000 1/min). (We do not give any voltage to the motor.)

2. The speeding up is performed in discrete steps (e.g. $1001 / \mathrm{min}$ ), reading the torque meter at each step. The torque - measured by the torque meter - is the bearing resistance torque, or the sum of the bearing and the brush resistance torques if a carbon brush is applied in the motor. As a result of the measurement we get one of the mentioned torques as a function of RPM. $(\mathrm{M}(\mathrm{n}))$

3. We determine function $M(\omega)$ from function $M(n)$, where $\omega$ is the angular speed of the motor in $\mathrm{rad} / \mathrm{s}$.

4. We release the clutch at the maximum RPM (e.g. $40001 / \mathrm{min}$ ) and let the motor slow down until it stops. We measure the RPM of the rotor - for example with an optical device - while the motor is slowing down. As a result we get the RPM as a function of time $(n(t))$.

5. We calculate the angular speed-time function $(\omega(\mathrm{t}), \mathrm{rad} / \mathrm{s})$ of the rotor from its RPM-time function.

6. We calculate the time derivative of function $\omega(\mathrm{t})$, this way we get the angular acceleration-time function of the rotor $(\varepsilon(t))$.

7. We calculate the value of the moment of inertia from corresponding $\varepsilon(t)$ and $M(\omega(t))$ values according to the following formula:

$$
J_{\text {rot }}=\frac{M(\omega(t))}{\varepsilon(t)}
$$

8. We calculate the mean value and standard deviation of the different $J_{\text {rot }}$ values.

The disadvantage of the method (version $\mathrm{A}$ ) is that we add the moment of inertia of a certain part of the clutch which is on the axis of the motor to the moment of inertia of the rotor during the measuring process (i.e. we must correct the measured value).

The process of measurement (version B):

1. We determine function $M(\omega)$ according to version $A$. (In this case, we do not need to apply a clutch).

2. We take the motor off the torque meter, then give voltage on it, and speed up it to a given RPM (eg. $40001 / \mathrm{min}$ ). After that we turn off the voltage and let the motor slow down until it stops. While the motor is slowing down, we measure the RPM of the rotor as a function of time $(n(t))$, for example applying an optical device.

3. From now on, we apply steps 5., 6., 7. and 8. according to version A. 
In case of version $\mathrm{B}$, it is a disadvantage that we need to rearrange the measurement system between the two measurements, and the motor can be magnetised, which may modify the results of the measurements. However, it is an advantage that it is not necessary to use a clutch for the measurements.

\section{Summary}

In our present publication we describe methods for measuring the dynamic characteristics of electric motors. We detailed several procedures for determining the moment of inertia of the rotor experimentally, and two different versions of a complex procedure for measuring the moments of inertia of rotor and the bearing and brush resistance torques together. We are working on developing our previous measurement system so that we can carry out run-out and dynamic test measurements on it. The developments include measuring the RPM with an optical device and building in a new, upto-date torque meter and a clutch. After we have made these improvements we are planning to carry out the measurements and evaluate the results, furthermore, we intend to use the obtained values of the determined dynamic characteristics in our vehicle dynamics simulation program.

Following this, we are going to carry out dynamic test measurements with the help of our improved measurement system - on a series wound DC motor - and compare the results with the results of the simulation. This comparison will give us feedback on the accuracy of our experimental procedure and the appropriate working of our simulation program.

\section{Acknowledgement}

Supported by the ÚNKP-18-2 New National Excellence Program of the Ministry of Human Capacities"

\section{References}

[1] Sziki, G. Á., Sarvajcz, K., Kiss, J., Gál, T., Szántó, A., Gábora, A., \& Husi, G. (2017) Experimental investigation of a series wound DC motor for modeling purpose in electric vehicles and mechatronics systems. Measurement. 109. pp. 111-118.

[2] Szántó, A., Sziki, G. Á., Hajdú, S., Gábora, A., \& Sipos, K. B. (2018). Járműdinamikai szimuláció és optimalizáció. Proceedings of the XXIII-RD International Conference of Young Engineers, Kolozsvár. pp. 219-222.

[3] Gábora, A., Szíki, G. Á., Szántó, A., Varga, T. A., Magyari, A., \& Balázs, D. (2017) Prototípus elektromos tanulmányautó fejlesztése a Shell Eco-Marathon ${ }^{\circledR}$ versenyre. In: A XXII. Fiatal Műszakiak Tudományos Ülésszak előadásai $=$ Proceedings of the XXII-th International ScientificConference of Young Engineers / szerk. Bitay Enikő, Erdélyi Múzeum Egyesület (EME), Kolozsvár. pp. 167-170.

[4] Juhász, Gy. (2013) Szakmai versenyek az oktatás szolgálatában = Technical competitions for the education In: Mankovits, Tamás (szerk.) Proceedings of the 1st international scientific 
conference on advances in mechanical engineering (ISCAME 2013) : 10-11 October 2013, Debrecen, Hungary Debrecen, Magyarország : Debreceni Egyetem Műszaki Kar. pp. 74-78.

[5] Nagy-Kondor, R. (2011) Technical mathematics in the University of Debrecen. Annales Mathematicae et Informaticae. 38 pp. 157-167.

[6] Nagyné, Kondor R. (2005) Special characteristics of engineer students' knowledge of functions. International Journal for Mathematics Teaching and Learning 10 pp. 1-9. , 9 p. (2005)

[7] Deák, K., Mankovits, T., \& Kocsis, I. (2017) Optimal Wavelet Selection for the Size Estimation of Manufacturing Defects of Tapered Roller Bearings with Vibration Measurement using Shannon Entropy Criteria. Strojniski Vestnik/Journal of Mechanical Engineering, 63(1).

[8] Deák, K., \& Kocsis, I. (2017) Support Vector Machine with Wavelet Decomposition Method for Fault Diagnosis of Tapered Roller Bearings by Modelling Manufacturing Defects. Periodica Polytechnica Mechanical Engineering, 61(4) pp. 276-281.

[9] Hajdu, S., \& Gáspár, P. (2016) Reducing the mast vibration of single-mast stacker cranes by gainscheduled control. International Journal of Applied Mathematics and Computer Science. 26(4) pp. 791-802.

[10] Hajdu, S., \& Gáspár, P. (2014) From modeling to robust control design of single-mast stacker cranes. Acta Polytechnica Hungarica, 11(10) pp. 135-149.

[11] Szántó, A., Szíki, G. Á., Hajdu, S., Gábora, A. (2017) Soros gerjesztésû egyenáramú motor szimulációja MATLAB környezetben = Simulation of a Series Wound DC Motor in MATLAB Environment In: Bitay, Enikő (szerk.) A XXII. Fiatal Műszakiak Tudományos Ülésszak előadásai : Proceedings of the XXII-th International Scientific Conference of Young Engineers Kolozsvár, Románia : Óbudai Egyetem, Erdélyi Múzeum Egyesület (EME). pp. 367-370. , 4 p.

[12] Szántó, A., Szíki, G. Á., Hajdu, S. (2016) Soros gerjesztésű egyenáramú motorral hajtott versenyautó dinamikai modellezése In: Bodzás, Sándor (szerk.) Műszaki tudomány az Észak-Kelet Magyarországi régióban 2016 Debrecen, Magyarország : Debreceni Akadémiai Bizottság Műszaki Szakbizottsága. pp. 587-591.

[13] Sziki, G. Á., Hajdu, S., Szántó, A. (2015) Vehicle dynamics modelling of an electric driven race car In: Sándor, Bodzás; Tamás, Mankovits (szerk.) Proceedings of the 3rd International Scientific Conference on Advances in Mechanical Engineering (ISCAME 2015) Debrecen, Magyarország : University of Debrecen Faculty of Engineering. pp. 208-217. 10 p.

[14] Ludvig Gy. (1983) Gépek dinamikája. Műszaki könyvkiadó, Budapest.

[15] Bodnár, D ; Hajdu, S (2018) Párhuzamos kinematikájú manipulátorok kinematikájának és munkaterének vizsgálata = Kinematics and Workspace analysis of parallel manipulators. International Journal of Engineering and Management Sciences / Müszaki és Menedzsment Tudományi Közlemények 3 (2) pp. 1-5. , 5 p.

[16] Szántó, A ; Hajdu, S (2018) Jármúvek menetdinamikai szimulációja Matlab/Simulink környezetben $=$ Vehicle dynamics simulation in Matlab/Simulink environment. International Journal of Engineering and Management Sciences / Múszaki és Menedzsment Tudományi Közlemények 3 (2) pp. 36-41., 6 p.

[17] Hajdú, S ; Gáspár, (2017)Robust Control of Single-Mast Stacker Cranes. Acta Polytechnica Hungarica 14 (4) pp. 105-119. 15 p.

[18] Hajdu, S., \& Gáspár, P. (2016) Reducing the mast vibration of single-mast stacker cranes by gainscheduled control. International Journal of Applied Mathematics and Computer Science, 26(4), pp. 791-802. 